\title{
BUSINESS MODEL IN ELECTRICITY INDUSTRY USING BUSINESS MODEL CANVAS APPROACH; THE CASE OF PT. XYZ
}

\author{
Ahmad Arief Wicaksono ${ }^{* 1}$, Rizal Syarief**), and Ono Suparno $\left.{ }^{* * *}\right)$ \\ *) PT. Bukaka Teknik Utama, Tbk \\ Raya Narogong Bekasi Road, KM. 19,5 Cileungsi, Bogor 16820 \\ **) Department of Food Science and Technology, Faculty of Agricultural Engineering and Technology, \\ Bogor Agricultural University, IPB Campus Darmaga, PO Box 220 Bogor 16002 \\ ${ }^{* * *}$ Department of Agroindustrial Technology, Faculty of Agricultural Engineering and Technology \\ Bogor Agricultural University, IPB Campus Darmaga, PO Box 220, Bogor 16002
}

\begin{abstract}
The magnitude of opportunities and project values of electricity system in Indonesia encourages PT. XYZ to develop its business in electrical sector which requires business development strategies. This study aims to identify company's business model using Business Model Canvas approach, formulate business development strategy alternatives, and determine the prioritized business development strategy which is appropriate to the manufacturing business model for PT. XYZ. This study utilized a descriptive approach and the nine elements of the Business Model Canvas. Alternative formulation and priority determination of the strategies were obtained by using Strengths, Weaknesses, Opportunities, Threats (SWOT) analysis and pairwise comparison. The results of this study are the improvement of Business Model Canvas on the elements of key resources, key activities, key partners and customer segment. In terms of SWOT analysis on the nine elements of the Business Model Canvas for the first business development, the results show an expansion on the power plant construction project as the main contractor, an increase in sales in its core business in supporting equipment industry of oil and gas, a development in the second business i.e. an investment in the electricity sector as an independent renewable emery-based power producer. On its first business development, PT. XYZ selected three Business Model Canvas elements which become the priorities of the company i.e. key resources weighing 0.252, key activities weighing 0.240, and key partners weighing 0.231. On its second business development, the company selected three elements to become their the priorities i.e. key partners weighing 0.225, customer segments weighing 0.217, and key resources weighing 0.215 .
\end{abstract}

Keywords: business model canvas, SWOT, pairwise comparison, business model

\begin{abstract}
ABSTRAK
Besarnya peluang dan nilai proyek sistem ketenagalistrikan di Indonesia membuat PT. XYZ melakukan pengembangan bisnisnya di sektor ketenagalistrikan, dan membutuhkan strategi pengembangan bisnis. Penelitian ini bertujuan mengidentifikasi model bisnis yang diterapkan saat ini dengan pendekatan Business Model Canvas, merumuskan alternatif strategi pengembangan bisnis dan menentukan prioritas strategi pengembangan bisnis untuk pembuatan model bisnis yang tepat bagi PT. XYZ. Penelitian ini menggunakan pendekatan deskriptif dan sembilan elemen Business Model Canvas. Rumusan alternatif dan penentuan prioritas strategi diperoleh dengan menggunakan analisis Strengths, Weaknesses, Opportunities, Threats (SWOT) dan pairwise comparison. Hasil penelitian ini adalah perbaikan Business Model Canvas pada elemen key resources, key activity, key partners dan customer segment. Hasil analisis SWOT terhadap sembilan elemen Business Model Canvas untuk pengembangan bisnis pertama yaitu ekspansi pada proyek pembangunan pembangkit listrik sebagai kontraktor utama, meningkatkan penjualan pada bisnis intinya di industri peralatan penunjang migas serta pengembangan bisnis kedua yaitu investasi pada sektor ketenagalistrikan sebagai produsen listrik swasta berbasis energi baru terbarukan. Pada pengembangan bisnis pertama PT. XYZ terpilih tiga elemen Business Model Canvas yang menjadi prioritas, yaitu key resources dengan bobot 0.252, key activities dengan bobot 0.240 dan key partners dengan bobot 0.231. Pada pengembangan bisnis kedua PT. XYZ terpilih tiga elemen Business Model Canvas yang menjadi prioritas, yaitu key partners dengan bobot 0.225, customer segments dengan bobot 0.217 dan key resources dengan bobot 0.215 .
\end{abstract}

Keywords: business model canvas, SWOT, pairwise comparison, model bisnis

${ }^{1}$ Corresponding author:

Email: ahmad_arief_wicaksono@yahoo.com 


\section{INTRODUCTION}

Infrastructure development is one of the important aspects in accelerating the national development process, improving competitiveness in the globalization era, and playing an important role to sustain the economic growth. The economic growth of a country cannot be separated from the availability of infrastructures including transportation, electricity and telecommunication systems, water supply, and irrigation. One of the significant deficiencies in the provision of infrastructure in Indonesia is the country's power system which does not meet the needs of the society in terms of both quality and quantity. This weakness can be seen from the low range and capacity of facilities and infrastructures in which the national electrification ratio was $84.4 \%$ in 2014 . In the period of 2015-2024, electricital needs in Indonesia are expected to increase from $219.1 \mathrm{TWh}$ in 2015 to $464.2 \mathrm{TWh}$ in 2024 , or grow at an average $8.7 \%$ per year, grow at an average of $7.8 \%$ per year in Java-Bali, grow at an average of $11.1 \%$ per year in East Indonesia, and grow at an average of $11.6 \%$ per year in Sumatera.

Based on Electricity Supply Business Plan (RUPTL) in 2015-2024 issued by PT. State-Owned Electricity Company (PT. PLN), to meet $6.7 \%$ of the economic growth, $8.8 \%$ of electricity demand, and electrification ratio of $97.4 \%$ in 2019 , it takes the development of infrastructure in electricity system covering the generated construction, transmission, and distribution of networks. The total value of the investment required to develop electricity system in Indonesia as a whole presumably built by PT. PLN and Independent Power Producer (IPP) is USD 83.429 billion in the period of 2015-2019.

The enormous opportunity of business potential on electricity system development projects in Indonesia, espcially power plants leads XYZ Group, as a multinational company engaged in the field of energy, oil and gas equipment (oil and gas), steel construction and telecommunications, to actively contribute and participate in the electricity system project. XYZ Group has conducted the business development through PT. $\mathrm{XYZ}$ as one of the nine strategic business units owned by XYZ Group. PT. XYZ is engaged in the business of oil and gas support equipment. In 2014, it succeeded in obtaining a contract for the power plant construction as much as 83 Mega Watt (MW) and other supporting facility construction. The total revenue earned by PT.
XYZ for both oil and non-oil and gas (power plant) in 2014 reached up to $40 \%$ of the total revenue of XYZ Group.

Power plant construction is a project with a high level of complexity. This is because the interdependence of the works, number of overlap potentials in their respective works, division of works into more detailed works, complexity of the organizational structure, duration of the overall project implementation and level of difficulty in preparing work schedules and budget for the project duration. Oil and gas project normally performed by PT. XYZ is simpler i.e. projects of procurement, production and maintenance.

One of the ways conducted by PT. XYZ to successfully run the business of both oil and non-oil power plants is to have the right business model in accordance with the goals and objectives set by the PT. XYZ management. It describes the rationale of how an organization creates, delivers and captures value (Osterwalder and Pigneur, 2012).

In reference to the issues faced by PT. XYZ, the objectives of this study are to identify the business model applied today by using Business Model Canvas approach, to formulate business development strategy alternatives, and determine the business development strategy priorities in the appropriate production of the business model for PT. XYZ.

Some related research utilizing the same method as this study had been conducted by Abdurrahim et al. (2014), Irawan et al. (2014), Kahraman et al. (2007), Rochman et al. (2011), Simbar (2013), Saints (2009) i.e by utilizing SWOT method to analyze the internal and external factors affecting the company. The results of the SWOT matrix were used to formulate an alternative strategy of business development. Ismail et al. (2013), Mazhaly et al. (2014), Permadi et al. (2015) and Saksono (2013) conducted a study with Business Model Canvas approach to obtain the right business model as a refinement and improvement of the current business model aiming to achieve the company's business development objectives.

Destiani (2014) examined an Analysis of Business Canvas Strategy at PT Angkasa Pura II on Soekarno Hatta International Airport by using Business Model Canvas approach, a SWOT analysis and pairwise comparison. The results of the analysis show that the 
BMC improvements for airport development in the future time are conducted by formulating strategies on the three elements i.e. key activities, key resources and channels.

These three elements are selected because of their major influence on the upcoming airport development. Strategic priorities on key elements of activities are the activity expansion and development on aeronautics and non-aeronautics. Strategic priorities on key resource elements are the revitalization and expansion of the airport non-aeronautical infrastructure. Thus, strategic priority on channels strategy is to make a complete and regularly updated airport website.

Dewobroto (2012) conducted a study on the Business Model Canvas as the Basis to Create Business Strategy Alternative and Feasibility. The study utilized Business Model Canvas approach, a SWOT and financial analyses to examine the business feasibility from the financial perspective. The results showed that the value of a car salon business should be emphasized on premium products, leisure and comfort of facility and final product with high quality and warranty. Key resources are prioritized on the professional human resources and use of qualified equipment and raw materials. To improve the company performance, the roles of partnership and third parties i.e. the suppliers, banks and credit card providers are necessary. Financially, the business payback period is an average of three years enabling it to be eligible to run. In reference to this research, it can be inferred that the Business Model Canvas can be a simple tool to generate an alternative strategy leading to the company's financial viability. The scope of this study is based on the formulation of the problems and research objectives of PT. XYZ. This study focused on the analysis of PT. XYZ development strategies and business model. The analysis is very important to be conducted after PT. XYZ has conducted its business development on the project of electricity system in Indonesia.

\section{METHODS}

The study was conducted at PT. XYZ located in Cileungsi, Bogor West Java from March - May 2016. PT. XYZ was selected intentionally (purposive) on the basis that the company is currently developing its business. The data utilized in this study were primary and secondary data. The primary data were the main sources of information required to reveal the research objectives. In this study, they were obtained from observations, focused-group discussions, and direct interviews with both internal and external respondents.

The primary data were required to identify the current business model covering the nine elements of the Business Model Canvas, analyze internal and external factors, and conduct weighting to determine the strategic priority in each business development at PT. XYZ. Thus, the secondary data were the source of information obtained from the company documents related to the issues studied by the supporting data from the literature, internet, scientific journals and results of previous studies.

This is a descriptive case study. According to Umar (2010), a case study aims to make a more detailed, in-depth and thorough study of a specific object which is usually relatively small in a certain period of time. A descriptive research method is used to obtain the overview of the information, explanations and conditions related to the object of study in a factual, accurate and systematic sense.

This study utilized a Business Model Canvas approach. SWOT analysis and pairwise comparison were also utilized on the nine elements of Business Model Canvas to formulate and determine strategy priorities on each business development of PT. XYZ, and they are then utilized to construct and improve the current Business Model Canvas.

Data and information collection were conducted by observations. Observations were perfomed on PT. $\mathrm{XYZ}$ business model in reference to the nine elements of the Business Model Canvas and the SWOT analysis process. Furthermore, focus-group discussions were conducted to obtain key information from internal respondents regarding the company's internal and external conditions.

Semi-structured interviews were also conducted to collect the data. The respondents in this study were classified into internal and external respondents. Internal respondents were selected based on the respondents' knowledge on the condition PT. XYZ specifically and their full authority in determining policies in PT. XYZ. Internal respondents of XYZ Group consisted of XYZ Group Director, PT. XYZ 
Director, Oil Project Manager, Non-oil Project Manager, Engineering Manager, Procurement Manager, Factory Manager, Quality Assurance Manager and Finance Manager. Meanwhile, the criteria for external respondents were selected based on the type of work, level of interest, and business relationship with PT. XYZ.

Thus, the external respondents included PT. ABC Project Owner, PT. DEF Project Owner, and PT. GHI Marketing Director. The involvement of external parties in this study was expected to produce the right business model for PT. XYZ. The interviews were performed by using pairwise comparison questionnaire on internal respondents carried out to determine the selected elements and strategic priorities. In addition, the literature study was conducted by studying and comprehending books, reports and a variety of references, as well as by collecting relevant data to the research objects.
To identify the PT XYZ business model currently being applied, the business model was identified through the nine elements of the Business Model Canvas i.e. customer segments, value proposition, channels, customer relationship, revenue streams, key resources, key activities, key partners, and cost structure. Hence, the next stage is to perform a SWOT analysis on the nine elements of the Business Model Canvas, in which they were a mixture of PT. XYZ internal and external conditions.

The formulation of business development strategy alternative was obtained from the SWOT matrix by means of matching strengths and opportunities (SO strategies), strengths and threats (ST strategies), weaknesses and opportunities (WO strategies), as well as weaknesses and threats (WT strategies). The next stage was to perform weighting by using pairwise comparison on each business development to determine the strategic priorities in selected Business Model Canvas element which is later used to improve and enhance the current business model. The research framework can be seen in Figure 1.

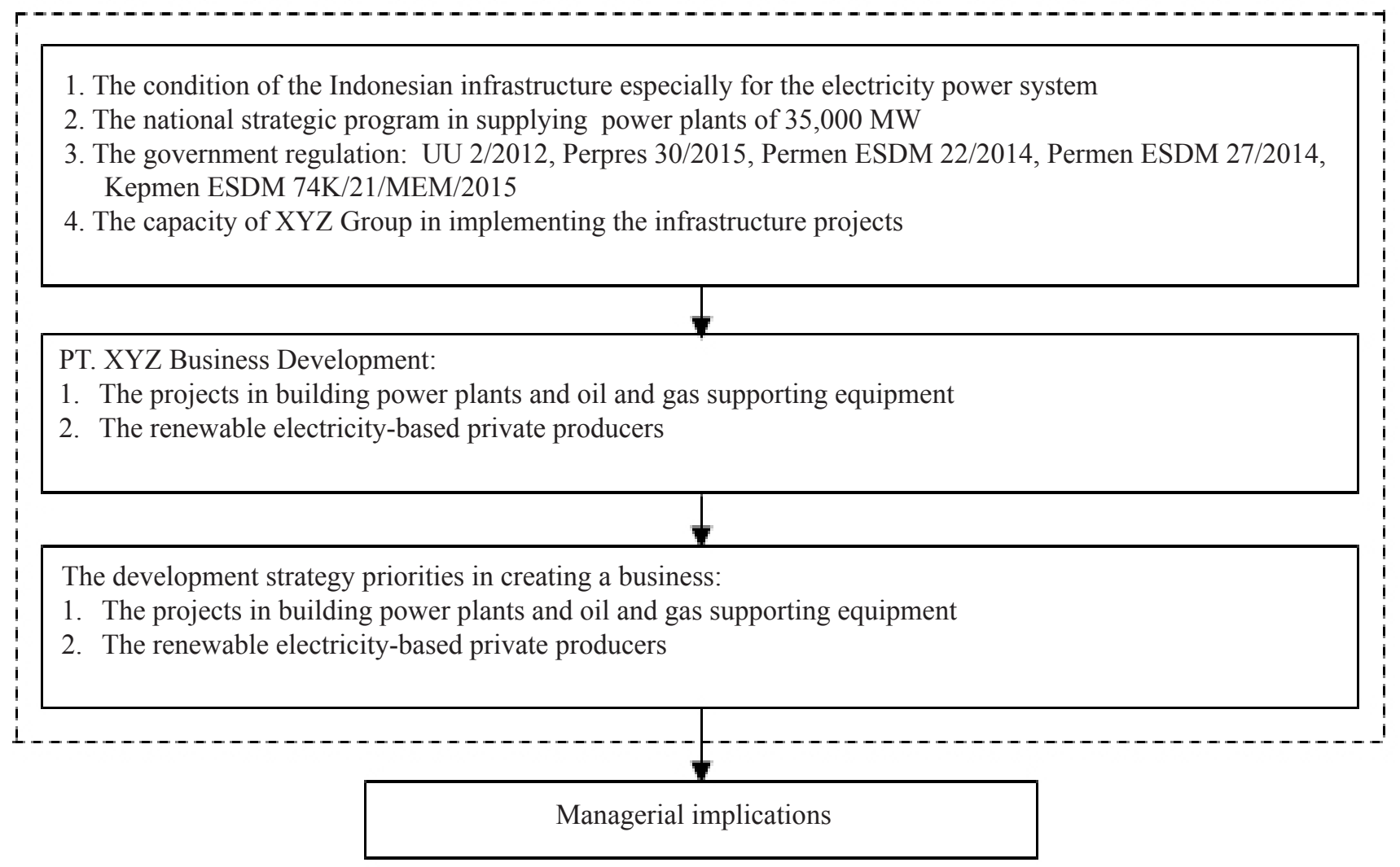

Research limitation

Figure 1. Research framework 


\section{RESULT}

\section{Identification on Elements of PT XYZ Business Model Canvas}

The results of identification on the nine elements of the PT. XYZ Business Model Canvas were obtained by conducting observations and Focus-Group Discussion on the internal respondents. The nine elements are interrelated and provide an overview of the state of PT. XYZ. Customer segments consist of both state-owned oil and gas companies and private companies from both domestic and abroad, contractors of Engineering Procurement Construction (EPC) and Independent Power Producer (IPP). This company has a value proposition as the market leader in pumping unit product, at minimum 25 years of experience in supporting oil and gas equipment industry, and it also has the easily accessible factory location, complete manufacturing facilities/infrastructure and capability of providing a warranty product with a standard period of $1.5 \mathrm{x}$.

PT. XYZ has three branch offices with various facilities for service and maintenance jobs located in Pekanbaru, Balikpapan and Makassar and eleven exclusive agents spread throughout Indonesia as distribution channels. Customer relationships are built through annual customer loyalty programs and customer community development program. Revenue streams are derived from supporting oil and gas product equipment sales and their spare parts, job services covering engineering design, service and maintenance, steel fabrication and construction as well as the work progress of a power plant $(2 \times 16.5 \mathrm{MW}$ and $2 \times 25 \mathrm{MW})$.

Key resources consist of human resources, manufacturing facilities, branch offices and credit facilities from banking institutions and non-banking financial agencies. Key activities in the form of production, service and maintenance, and site construction work at the project site. Key partners consist of suppliers, subcontractors, exclusive agents, banking institutions and non-banking financial agencies. Thus, the cost structure consists of the costs of production, marketing, site construction, investment and development.

\section{SWOT Analysis and Strategic Alternatives of PT XYZ Business Development}

The following stage after identifying PT. XYZ business model was to conduct a SWOT analysis on the nine elements of Business Model Canvas obtained from the observations, focus-group discussions with the internal respondents, and interviews with the external respondents. SWOT analysis on the nine elements of PT. XYZ Business Model Canvas can be seen in Table 1.

The results of SWOT analysis were matched with the internal (strengths and weaknesses) and external (opportunities and threats) factors to obtain strategic alternatives i.e. SO, WO, ST and WT strategies. PT. $\mathrm{XYZ}$ business development strategies can be seen in Table 2.

\section{Strategic Priority of PT XYZ Business Development}

PT. XYZ has made an attempt to meet the expectations of the investors, public, shareholders and other stakeholders of the company aiming to thrive among the vast growth of dynamics and challenges in both domestic and global levels by performing business development. The first PT. XYZ business development functions to expand the power plant construction project as the main contractor and increase sales in its core business in the oil and gas supporting equipment industry both at the domestic and abroad scopes. Thus, the second business development of PT. XYZ is performed by investing in the electricity sector as an independent renewable energy-based power producer, particularly that of biomass and biogas.

\section{The first business development of PT. XYZ}

In reference to the interview results with the internal respondents and calculation by pairwise comparison method utilizing expert choice 2000software, three elements of Business Model Canvas were selected as priorities to the development of PT. XYZ first business. The third element of the Business Model Canvas was key resource weighing up to 0.252 (WO2 strategy weighing 0.353 and WO1 strategy weighing 0.328 ; CR: 0.03). 
Table 1 The result of SWOT Analysis on the elements of PT XYZ nine Business Model

\begin{tabular}{|c|c|c|c|c|}
\hline Element & Strength (S) & Weakness (W) & Opportunity (O) & Threat (T) \\
\hline $\begin{array}{l}\text { Customer } \\
\text { segments }\end{array}$ & $\begin{array}{l}\text { - Customer network } \\
\text { - Company capacity } \\
\text { - Product variation }\end{array}$ & $\begin{array}{l}\text { - Lack of experience in } \\
\text { power plant industry }\end{array}$ & $\begin{array}{l}\text { - Oil and gas potentials } \\
\text { in Middle East } \\
\text { - } 35,000 \text { MW Program } \\
\text { - } 1,227 \text { MW EBT }\end{array}$ & $\begin{array}{l}\text { - Decrease of oil and gas } \\
\text { onshore production } \\
\text { - Lack of power domestic } \\
\text { component level of } \\
\text { power plant industry } \\
\text { (Kumara, 2009) }\end{array}$ \\
\hline Value proposition & $\begin{array}{l}\text { - Market leader } \\
\text { - API standard quality } \\
\text { - Plant location, } \\
\text { branch offices } \\
\text { - Warranty of } 1.5 \mathrm{x} \\
\text { period }\end{array}$ & $\begin{array}{l}\text { - Disintegrated NCR } \\
\text { Data } \\
\text { - No published product } \\
\text { maintenance schedules }\end{array}$ & $\begin{array}{l}\text { - Product innovation } \\
\text { - } \text { Bundling contract } \\
\text { - } \text { Direct assignment }\end{array}$ & In Genuine spare parts \\
\hline Channels & $\begin{array}{l}\text { - } 3 \text { branch offices } \\
\text { - } 11 \text { exclusive agent }\end{array}$ & $\begin{array}{l}\text { - Unpredictable } \\
\text { availability of Spare } \\
\text { parts } \\
\text { - Single production line }\end{array}$ & $\begin{array}{l}\text { Bundling contract project } \\
\text { in Oman }\end{array}$ & $\begin{array}{l}\text { Partnership offers from } \\
\text { competitors toward } \\
\text { exclusive agents }\end{array}$ \\
\hline $\begin{array}{l}\text { Customer } \\
\text { relationship }\end{array}$ & $\begin{array}{l}\text { - Customer loyalty } \\
\text { program } \\
\text { - Customer } \\
\text { community } \\
\text { development }\end{array}$ & $\begin{array}{l}\text { - Customer relationship } \\
\text { budgets }\end{array}$ & $\begin{array}{l}\text { New business } \\
\text { opportunity and access to } \\
\text { stakeholders }\end{array}$ & $\begin{array}{l}\text { - Unhealthy competition } \\
\text { - Unsynchronized } \\
\text { government policies }\end{array}$ \\
\hline Revenue streams & $\begin{array}{l}\text { - Product marketing, } \\
\text { work progress } \\
\text { - Productivity and } \\
\text { efficiency }\end{array}$ & $\begin{array}{l}\text { - Inappropriate cross } \\
\text { subsidy } \\
\text { - Limited working capital } \\
\text { - Inaccurate } \\
\text { administration }\end{array}$ & $\begin{array}{l}\text { - Large capital foreign } \\
\text { investors with large } \\
\text { capital } \\
\text { - Electricity requirement } \\
\text { for the CPO producing } \\
\text { companies }\end{array}$ & $\begin{array}{l}\text { - Decrease of oil prices } \\
\text { - Project penalty } \\
\text { - Payment system is } \\
\text { not in accordance } \\
\text { with the schedule and } \\
\text { commitment }\end{array}$ \\
\hline Key resources & $\begin{array}{l}\text { - Plant facilities } \\
\text { - Empty area of } 13 \\
\text { Ha } \\
\text { - Policy on business } \\
\text { investment in EBT } \\
\text { electricity }\end{array}$ & $\begin{array}{l}\text { - Limitation in credit } \\
\text { plafond } \\
\text { - Inexperienced human } \\
\text { resources } \\
\text { - STO does not cover } \\
\text { the power supply plant } \\
\text { project }\end{array}$ & $\begin{array}{l}\text { - EBT potentials are not } \\
\text { maximal } \\
\text { - Foreign investors on } \\
\text { EBT }\end{array}$ & $\begin{array}{l}\text { - High interest of loan } \\
\text { - Fluctuation of foreign } \\
\text { currency values } \\
\text { - Discrepancies in credit } \\
\text { disbursement versus } \\
\text { project cash flow }\end{array}$ \\
\hline Key activities & $\begin{array}{l}\text { - Stable oil and gass } \\
\text { business process } \\
\text { - Production machine } \\
\text { facilities }\end{array}$ & $\begin{array}{l}\text { - Employee demography } \\
\text { - Electric power plant } \\
\text { mismanagemnt } \\
\text { - Limitation of } \\
\text { employees with } \\
\text { appropriate expertise or } \\
\text { knowledge required }\end{array}$ & $\begin{array}{l}\text { - EBT operator company } \\
\text { - Supply of manpower } \\
\text { from the high } \\
\text { education institutions }\end{array}$ & $\begin{array}{l}\text { - Decrease of procurement } \\
\text { project of oil and gas } \\
\text { - Low responses from the } \\
\text { consultants of electricity } \\
\text { plant }\end{array}$ \\
\hline Key partners & $\begin{array}{l}\text { - Strategic partner } \\
\text { network } \\
\text { - Access to iron steel } \\
\text { factories }\end{array}$ & $\begin{array}{l}\text { - Late loan payment } \\
\text { - Selection and } \\
\text { assessment on suppliers } \\
\text { are not maximal } \\
\text { - No consultants in } \\
\text { electricity plant project }\end{array}$ & $\begin{array}{l}\text { - Needs for oil and gas } \\
\text { products in the middle } \\
\text { east } \\
\text { - Steel construction } \\
\text { expansion } \\
\text { - Electricity policy in } \\
\text { EBT Local government } \\
\text { - The CPO plants are } \\
\text { unable to process their } \\
\text { wastes into electricity }\end{array}$ & $\begin{array}{l}\text { - Take over of work by the } \\
\text { project owner } \\
\text { - Consultants and } \\
\text { customers have direct } \\
\text { access to the suppliers } \\
\text { - Decrease customer trust } \\
\text { level }\end{array}$ \\
\hline Cost structure & $\begin{array}{l}\text { - Funding sources } \\
\text { from banks }\end{array}$ & $\begin{array}{l}\text { - High overhead } \\
\text { - Payment policy to XYZ } \\
\text { group } \\
\text { - Inappropriate cashflow } \\
\text { realization }\end{array}$ & $\begin{array}{l}\text { - Free trade agreement } \\
\text { - Funding from } \\
\text { international finance } \\
\text { agency }\end{array}$ & $\begin{array}{l}\text { - Increase of regional } \\
\text { minimum wages } \\
\text { - Postponement of oil and } \\
\text { gas projects }\end{array}$ \\
\hline
\end{tabular}


Table 2. Strategic Alternatives of PT. XYZ Business Development

\begin{tabular}{|c|c|}
\hline Elements & Strategic Alternatives \\
\hline Customer segments & $\begin{array}{l}\text { Middle Eat Market (SO1); customer targets of PT. PLN (SO2); Contract review (WO1); } \\
\text { Communication and Coordination (ST1); Product Diversification \& Transfer of Technology } \\
\text { (WT1) }\end{array}$ \\
\hline Value proposition & $\begin{array}{l}\text { Design review (SO1); Project Control (SO2); Standard Procedures (WO1); Spare part stocks } \\
\text { (ST1); Preventive \& predictive maintenance (WT1) }\end{array}$ \\
\hline Channels & $\begin{array}{l}\text { Joint operation (SO1); Online system of spare parts(WO1); pumping unit production C1280 } \\
\text { (WO2); TQM system (ST1); EOQ system (Susanti et al. 2015) (WT1) }\end{array}$ \\
\hline Customer relationship & $\begin{array}{l}\text { Increasing of CRM frequency and quality (SO1); Collaboration with XYZ Group (WO1); GCG } \\
\text { Implementation (ST1); CRM XYZ Group (WT1) }\end{array}$ \\
\hline Revenue streams & $\begin{array}{l}\text { EBT Company Visit (SO1); Issuance of STO, policies, supporting infrastructure (WO1); } \\
\text { Expeditor assignment in suppliers(ST1); Qualified project manager (WT1) }\end{array}$ \\
\hline Key resources & $\begin{array}{l}\text { EBT Subsidiaries (SO1); Right issues (WO1); Recruitment of professionals and experienced } \\
\text { workers (WO2); Feasibility study of investment program (ST1); Hedging on import purchasing } \\
\text { (WT1) }\end{array}$ \\
\hline Key activities & $\begin{array}{l}\text { Company infrastructure as EBT operator (SO1); Recruitment system and employee } \\
\text { development (WO1); Strengthening of the Project Management Department and establishment } \\
\text { of Risk Management Department (ST1); Business development outside oil and gas (ST2); } \\
\text { Employee restructuration and machine automatization (WT1) }\end{array}$ \\
\hline Key partners & $\begin{array}{l}\text { Investment feasibility study in Middle East (SO1); Blanket order with suppliers (SO2); } \\
\text { Cooperation with the CPO production company and the Local Government in EBT (SO3); } \\
\text { Competitive Tender (WO1); Reliable and experienced consultants (WO2); Assignment for } \\
\text { engineers and reps of QC in suppliers (ST1); Joint operation (WT1) }\end{array}$ \\
\hline Cost structure & $\begin{array}{l}\text { Bank and finance agency partnership (local/foreign) (SO1); Direct purchase to factories (WO1); } \\
\text { Efficiency and budget rules (ST1); Function-added cost control in STO PM (WT1) }\end{array}$ \\
\hline
\end{tabular}

WO2 strategy consists of recruiting professionals and experienced (local/ expatriate) workers in the field of power plant, particularly in engineering department. According to Georgy et al. (2006), engineering performance in the construction industry directly affects the overall performance of the project. Meanwhile, WO1 strategy functions to issue new shares/right issues to strengthen its capital structure. In this matter, right issues can be interpreted as the issuance of new shares by a public company aiming to finance business expansion, increase working capital or pay the loan (Ellitan, 2006).

Key activities have the weight up to 0.240 (ST1 strategy weighing 0.423; CR: 0.07). ST1 strategy functions to strengthen the project management department and form a risk management department with duties, responsibilities and authority in accordance with the needs and characteristics of the power plant projects. The scope of extensive work, great contract value or work complexity require the role of project management to integrate all of the activities and resources in the power plant construction project (Roeshardianto et al. 2015).
Key partners have the weight up to 0.231 (WO2 strategy weighing 0.301 and WT1 strategy weighing 0.295; CR: 0.08). WO2 strategy functions to recruit reliable and experienced consultants in project planning and implementation process, while WT1 strategy is conducted by establishing partnership/strategic partners to the joint operation scheme in power plant construction projects.

Consitency Ratio (CR) Value of each strategy is less than 0.1 meaning that the comparison is consistent. This is in line with what is revealed by Marimin and Maghfiroh (2011) in which the ratio is considered to be consistent if CR is not more than 0.1 .

The third strategic priority on the selected element is considered to be a significant influence on other elements in the first business development of PT. XYZ. The optimal use of key resources in the presence of professional and experienced workers who are aware and comprehend the engineering process, material standard and its equivalence, waste materials and the workflow in power plant construction project will provide effectiveness and cost-efficiency in the cost structure, particularly in the production material provision and site construction costs. 
The selection of the key partners who are competent and qualified was conducted by utilizing core resources owned by partners; starting from the planning stage to the handover stage supported by accurate and reliable projects, and risk management systems on the key activity elements enable PT. XYZ to achieve its target on time, on quality and on budget work progress.

Hence, customer satisfaction eventually creates a sense of trust and added value, which therefore, enables PT. $\mathrm{XYZ}$ to obtain larger projects and increased revenue stream. Strategic priorities obtained from the weighting of the key resources, key activities, and key partners in PT. XYZ are utilized to create the right business model as an improvement and refinement of the current business model, as shown in Figure 2.

\section{The second business development of PT. XYZ}

Based on the interview results with the internal respondents and weighting by utilizing pairwise comparison method with expert choice 2000 software, three elements of Business Model Canvas were selected as the priorities for the second business development of PT. XYZ. The third element of Business Model Canvas is key partner weighing 0.225 (SO3 strategy weighing
0.268 and WT1 strategy weighing 0.267 ; CR: 0.08 ). Thus, SO3 strategy functions to establish cooperation with $\mathrm{CPO} /$ palm oil production companies and the Local Government in the provision of biomass and biogas power plants. Meanwhile, WT1 strategy is conducted by establishing partnerships/strategic partners with the joint operation scheme in invesments in biomass and biogas power plant. Joint operation is a combination of commercial organizations, corporations, partnerships and others, collaborating to produce a cooperation contract or project (Lumeno, 2011).

Customer segments have the weight up to 0.217 (SO2 strategy weighing $0.433 ; \mathrm{CR}: 0.05)$. SO2 strategy enables PT. PLN (State-Owned Enterprise) to become the main targeted customer in the biomass and biogas electricity power supply. Thus, key resources have the weight up to 0.215 (SO1 strategy weighing 0.335 and WO2 strategy weighing 0.322 ; CR: 0.06). SO1 strategy affects a subsidiary engaged in biomass and biogas electricity power supply. Meanwhile, WO2 strategy functions to recruit professionals and experienced (local/expatriate) workers in the field of biomass and biogas power plants ranging from the study process of feasibility, planning, design, construction, operation and maintenance.

\begin{tabular}{|c|c|c|c|c|}
\hline \multirow{2}{*}{$\begin{array}{l}\quad \text { Key Partners } \\
\text { - Suppliers } \\
\text { - Subcontractors } \\
\text { - Exclusive agents } \\
\text { - Banking Institutions } \\
\text { - EPC Project } \\
\text { Consultant } \\
\text { - Strategic partners/ } \\
\text { partnership (joint } \\
\text { operation) - } \\
\text { PLTBm/g }\end{array}$} & $\begin{array}{l}\quad \text { Key Activities } \\
\text { - Production } \\
\text { - Service \& mainte- } \\
\text { nance } \\
\text { - Site construction } \\
\text { - Project management } \\
\text { dan Risk } \\
\text { management }\end{array}$ & \multirow{2}{*}{$\begin{array}{l}\text { Value Proposition } \\
\text { - Market leader of } \\
\text { pumping unit product } \\
\text { - Experienced in Oil } \\
\text { and Gas supporting } \\
\text { equipment industry (> } \\
25 \text { years) } \\
\text { - Easily accessible plant } \\
\text { location } \\
\text { - Equipped Plant } \\
\text { facility/infrastructure } \\
\text { - Period of Product } \\
\text { Warranty of } 1.5 \mathrm{x} \text { the } \\
\text { standard period }\end{array}$} & $\begin{array}{l}\text { Customer Relationships } \\
\text { - Customer loyalty } \\
\text { program } \\
\text { - Customer community } \\
\text { development }\end{array}$ & \multirow[t]{2}{*}{$\begin{array}{l}\text { Customer Segments } \\
\text { - Oil and Gas Companies } \\
\text { (State-Owned and } \\
\text { Private Enterprises) } \\
\text { - EPC Contractor } \\
\text { - Independent Power } \\
\text { Producer (IPP) }\end{array}$} \\
\hline & $\begin{array}{l}\text { Key Resources } \\
\text { - Human Resources } \\
\text { - Factory and Branch Of- } \\
\text { fice Facilities } \\
\text { - Bank Loans } \\
\text { - Professional (local/ } \\
\text { expat) workers - } \\
\text { PLTBm/g } \\
\text { - Right issue shares }\end{array}$ & & $\begin{array}{l}\text { Channels } \\
\text { - Three Branch } \\
\text { Offices (Pekanbaru, } \\
\text { Balikpapan, Makasar) } \\
\text { - Eleven exclusive } \\
\text { agents }\end{array}$ & \\
\hline \multicolumn{2}{|l|}{$\begin{array}{l}\text { - Production Cost } \\
\text { - Marketing Cost } \\
\text { - Site construction Co } \\
\text { - Investment and Dev }\end{array}$} & \multicolumn{3}{|c|}{$\begin{array}{l}\text { - Sales of supporting equipment products of oil and gas including their } \\
\text { spare parts, services (engineering design, service and maintenance), } \\
\text { fabrication and construction of iron steel } \\
\text { - Progress on power plant construction }((2 \times 16.5 \mathrm{MW} \text { and } 2 \times 25 \\
\underline{\mathrm{MW})}\end{array}$} \\
\hline
\end{tabular}

Notes: Bold (elements of improvement and perfection ); Underline (impact of elements of construction and perfection)

Figure 2. Business Model Canvas of PT. XYX for its first business development 
Strategic priorities on the elements of key partners, customer segments and key resources in making investment in the electricity sector, as an independent power producer based on renewable energy, especially biomass and biogas power plants, have an important role and a significant influence on the elements of the revenue stream that is an addition of alternative revenue sources in the forms biomass and biogas power sales to PT. PLN (State-Owned Enterprise).

Alternative revenue sources are expected to maintain PT. XYZ business continuity in the future. Strategic priorities obtained from weighting key partner elements, customer segments and key resources of PT. $\mathrm{XYZ}$ are used to create the right business model as an improvement and perfection of the current business model, as shown in Figure 3.

\section{Managerial Implications}

On the first business development of PT. XYZ, strategic priorities of key resource element included WO2 and WO1 strategies. WO2 strategy is performed by recruiting professionals and experienced (local/ expatriate) workers in the field of power generator. The steps required to be taken by the PT XYZ management are as follow: establishing the policies of HRD department; improving recruitment models by applying outsourcing system, managment trainee program, talent management; conducting evaluation and improvement of the remuneration system; utilizing Plant Design Management System (PDMS) software. Meanwhile, WO1 strategy is performed to issue new shares/right issues. The steps required to be taken by PT. XYZ include proposing an approval from the shareholders to implement the corporate action (right issue) through the Annual General Extraordinary Shareholder Meeting (EGM).

The strategic priority of key activity elements is ST1 strategy functioning to strengthen the project management department and form a risk management department with the duties, responsibilities and authority in line with the needs and characteristics of power plant projects. The steps required to be taken by PT. XYZ management are: creating an organizational structure, standard operating procedures and human resource planning in reference to the needs of companies and the project characteristics; providing supporting tools/ software; and implementing ISO 3100: 2009 regarding the risk management on all projects of PT. XYZ.

\begin{tabular}{|c|c|c|c|c|}
\hline \multirow{2}{*}{$\begin{array}{l}\quad \text { Key Partners } \\
\text { - Suppliers } \\
\text { - Subcontractors } \\
\text { - Exclusive agents } \\
\text { - Banking Institutions } \\
\text { - CPO Production } \\
\text { Companies and Local } \\
\text { Governments } \\
\text { - Strategic partners/ } \\
\text { partnership (joint } \\
\text { operation) - } \\
\text { PLTBm/g }\end{array}$} & $\begin{array}{l}\quad \text { Key Activities } \\
\text { - Production } \\
\text { - Service \& maintenance } \\
\text { - Site construction }\end{array}$ & \multirow{2}{*}{$\begin{array}{l}\text { Value Proposition } \\
\text { - Market leader of } \\
\text { pumping unit product } \\
\text { - Experienced in Oil } \\
\text { and Gas supporting } \\
\text { equipment industry (> } \\
25 \text { years) } \\
\text { - Easily accessible plant } \\
\text { location } \\
\text { - Equipped Plant } \\
\text { facility/infrastructure } \\
\text { - Period of Product } \\
\text { Warranty of } 1.5 \mathrm{x} \text { the } \\
\text { standard period }\end{array}$} & $\begin{array}{l}\text { Customer Relationships } \\
\text { - Customer loyalty } \\
\text { program } \\
\text { - Cstomer community } \\
\text { development }\end{array}$ & \multirow[t]{2}{*}{$\begin{array}{l}\text { Customer Segments } \\
\text { - Oil and Gas Companies } \\
\text { (State-Owned and } \\
\text { Private Enterprises) } \\
\text { - EPC Contractor } \\
\text { - Independent Power } \\
\text { Producer (IPP) } \\
\text { - PT. PLN (Persero) }\end{array}$} \\
\hline & $\begin{array}{l}\text { Key Resources } \\
\text { - Human Resources } \\
\text { - Factory and Branch Of- } \\
\text { fice Facilities } \\
\text { - Bank Loans } \\
\text { - Subsidiaries in } \\
\text { PLTBm/g } \\
\text {-Professional (local/expat) } \\
\text { workers - PLTBm/g }\end{array}$ & & $\begin{array}{l}\text { Channels } \\
\text { - Three Branch } \\
\text { Offices (Pekanbaru, } \\
\text { Balikpapan, Makasar) } \\
\text { - Eleven exclusive } \\
\text { agents }\end{array}$ & \\
\hline \multicolumn{2}{|c|}{$\begin{array}{l}\text { - Production Cost } \\
\text { - Marketing Cost } \\
\text { - Site construction Cost } \\
\text { - Investment and Development Cost }\end{array}$} & & \multicolumn{2}{|c|}{$\begin{array}{l}\text { - Sales of supporting equipment products of oil and gas including their } \\
\text { spare parts, services (engineering design, service and maintenance), } \\
\text { fabrication and construction of iron steel } \\
\text { - Progress on power plant construction ( } 2 \text { x } 16.5 \mathrm{MW} \text { and } 2 \times 25 \\
\text { MW) } \\
\text { - } \text { Sales of electricity with biomass and biogas power }\end{array}$} \\
\hline
\end{tabular}

Notes: Bold (elements of improvement and perfection ); Underline (impact of elements of construction and perfection)

Figure 3. PT. XYZ Business Model Canvas for the second business development 
The strategic priorities of key partner elements are $\mathrm{WO} 2$ and WT1 strategies. Firstly, WO2 strategy recruits reliable and experienced consultants for services in planning and implementing projects. The steps required to be taken by PT. XYZ management are: establishing proportional budgets, determining work scope and time duration in using the consultant services. Thus, WT1 strategy takes a strategic partnership (joint operation) in working on power plant construction projects. The steps required to be taken are performing an assessment and establishing assessment criteria on strategic partners; building cooperation with government and chamber of commerce from partnering countries to avoid broker companies; issuing partnership contract with joint operation scheme in accordance with both parties' agreement.

On the second business development of PT. XYZ, strategic priorities of key partner elemets are $\mathrm{SO} 3$ and WT1 strategies. SO3 strategy functions to establish cooperation with the Crude Palm Oil (CPO) production company and the Local Government. The steps required to be taken by $\mathrm{PT}$. XYZ management are: conducting a feasibility study on biomass and biogas energy investment; providing insights into the Local Government biomass and biogas energy potentials; establishing intensive communication and facilitating stakeholders to realize the Biomass Power Plant (PLTBm) and Biogas Power Plant (PLTBg).

Moreover, WT1 strategy is performed by establishing a strategic partnership with joint operation scheme in investing biomass and biogas power plants. The steps required to be taken are conducting assessment and establishing its criteria for strategic partners; cooperation with the government and home countries' chamber of commerce to avoid broker companies; issuing contracts with joint operation scheme in accordance with agreement of both parties. Strategic priority of customer segment elements is $\mathrm{SO} 2$ strategy enabling PT. PLN as the major targeted customer in the biomass and biogas energy power supply.

The necessary steps required to be taken by PT. XYZ management are as follow: conducting technical and commercial approach on biomass and biogas power plant development on PT. PLN; reporting the progress and coordinating with PT. PLN at central and local levels regarding the investment progress. Strategic priority of key resource elements are SO1 and WO2 strategies. SO1 strategy encourages subsidiary engaging in the field of biomass and biogas energy power supply. The steps required to be taken by PT. XYZ management are completing the legality of the company establishment and proposing for Electricity Supply Business License (IUPTL). Meanwhile, WO2 strategy is performed by recruiting professionals and experienced (local/ expatriate) workers in the field of power plants biomass and biogas. The required steps are establishing the policies of HRD department; improving the recruitment models by applying outsourcing system, MT program, talent management; conducting evaluation and improvement of the remuneration system.

\section{CONCLUSIONS AND RECOMMENDATIONS}

\section{Conclusions}

The identification results of the nine elements of current PT. XYZ Business Model Canvas include customer segments of State-Owned Enterprises and private oil and gas companies, contractors of Engineering Procurement Construction (EPC), independent power producers; value proposition as the market leader in pumping unit product, affordable plant location, equipped plant facilities, product warranty in a standard period of $1.5 \mathrm{x}$; channels in the form of three branch offices and eleven exclusive agents; customer relationships through customer loyalty programs and customer community development; revenue stream derived from oil and gas supporting equipment product sales, steel fabrication construction, power plant construction progress; key resources consisting of human resources, factories, offices, bank credits; key activities in forms of production, service and maintenance, site construction; key partners consisting of suppliers, subcontractors, exclusive agents, banking, and cost structures e.g. costs of production, marketing, site construction, investment and development.

SWOT analysis on the nine elements of Business Model Canvas for the first business development is the expansion of the power plant construction project as the main contractor, increased sales in its core business in oil and gas supporting equipment industry. Furthermore, the second business development is the investment in the electricity sector as an independent renewable energy-based power supply, generating alternatives as follow: five strategies of customer segments, five strategies of value proposition, five 
strategies of channels, four strategies of customer relationships, revenue streams: four strategies of customer relationships, five strategies of key resources, six strategies of key activities, seven strategies of key partners, four strategies of cost structure.

On the first business development of PT. XYZ, three elements of Business Model Canvas were selected as priorities i.e. key resources weighing 0.252 , key activities weighing 0.240 , and key partners weighing 0.231 . The first strategic priority for the key resource elements is to recruit professionals and experienced (local/expatriate) workers in the field of power supply from a variety of disciplines, particularly in the technical field in line with the needs of the project. Meanwhile, the second strategic priority is to issue new shares/right issues to strengthen its capital structure in conducting business expansion and strategic project funding.

Strategic priorities for key activity elements are to strengthen the project management department and form a risk management department with the duties, responsibilities and authority in line with the needs and characteristics of power plant projects. The first strategic priority for key partner elements is to hire reliable and experienced consultants for services in project planning and implementation, while the second strategic priority is to establish strategic partnership with the joint operation scheme in power plant construction projects. Construction and improvement to these elements will affect cost structure elements (production material supply costs and site construction) and revenue streams.

On the second business development of PT. XYZ, three elements of Business Model Canvas were selected as the priorities i.e. key partners weighing 0.225 , customer segments weighing 0.217 and key resources with a weight of 0215 . The first strategy priorities for the key partner elements is to establish cooperation with the CPO production companies and Local Governments in the provision of biomass and biogas power energy, while the priority of the second strategy is to establish strategic partnership with joint operation scheme in investment in biomass and biogas power plants.

The strategic priority for customer segment element has made PT. PLN as the major customer target in the supply of biomass and biogas power energy. The first strategy priority for key resource elements is making subsidiary to be engaged in the field of biomass power and biogas energy supply, while the priority of the second strategy is to recruit professional and experienced (local/expatriate) workers in the field of biomass and biogas power plants from the process of the feasibility, planning, design, construction, operation and maintenance. Construction and improvements to these elements will affect the revenue stream element i.e. the addition of alternative income sources in forms of biomass and biogas power sales.

\section{Recommendations}

PT. XYZ management is recommended to perform socialization to the stakeholders of XYZ Group management and its employees regarding the strategic priorities that have been set up, so that the expected implementation of the strategy will be effective and supported by all parties. This study becomes an outset to conduct further studies regarding the analysis on the strategic implementation, effectiveness of the strategy, and strategic evaluation to enrich the research on PT. XYZ business development. The research on a business model by using Business Model Canvas approach should be broadened in scope i.e. they are not limited to only companies, but also to the electricity industry as a whole releated to power plants and renewable energy development projects

\section{REFERENCES}

Abdurrahim MFH, Daryanto A, Nurmalina R. 2014. Strategi pengembangan balai penelitian bioteknologi perkebunan Indonesia. Jurnal Manajemen dan Agribisnis 11(3): 199-208.

Destiani DP. 2014. Analisis strategi model bisnis kanvas pada PT Angkasa Pura II untuk Bandara Internasional Soekarno-Hatta [tesis]. Bogor: Institut Pertanian Bogor.

Dewobroto WS (2012). Business model canvas sebagai dasar untuk menciptakan alternatif strategi bisnis dan kelayakan usaha. Jurnal Teknik Industri 2(3): 215-230.

Ellitan L. 2006. Strategi inovasi dan kinerja perusahaan manufaktur di Indonesia: pendekatan model simultan dan model sekuensial. Jurnal Manajemen 6(1): 1-22.

Georgy ME, Chang LM, Zhang L. 2006. Engineering performance in the US industrial construction sector. Journal of Cost Engineering 47(1): 27- 
36.

Irawan RR, Sumarwan U, Djohar S. 2014. Model bisnis industri tambang timah berkelanjutan (studi kasus Bangka Belitung). Jurnal Aplikasi Manajemen 12(2): 197-207.

Ismail R, Irawati L, Dahlan D, Putri NIS, Nasuha A, Sulistyoningsih. 2013. Model bisnis perbankan syariah. Journal of Islamic Economics Finance and Banking 1(2): 183-198.

Kahraman C, Nihan CD, Taufan D. 2007. Prioritization of e-government strategies using SWOT-AHP analysis: The case of Turkey. European Journal of Information System 16(8): 284-298. https:// doi.org/10.1057/palgrave.ejis.3000679.

Lumeno SS. 2011. Masalah budaya dalam proyek international joint operation. Jurnal Ilmiah Media Engineering 1(2): 144-149.

Marimin, Maghfiroh N. 2011. Aplikasi Teknik Pengambilan Keputusan Dalam Manajemen Rantai Pasok. Bogor: IPB Press.

Mazhaly N, Umar DD, Moengin P. 2014. Penerapan blue ocean strategy di PT. X dalam menghadapi persaingan penjualan automatic tank gauging di Indonesia. Jurnal Teknik Industri 3(2): 241254.

Osterwalder A, Pigneur Y. 2012. Business Model Generation (terjemahan). Jakarta: PT. Elex
Media Komputindo.

Permadi B, Nurmalina R, Kirbrandoko. 2015. Analisis pengembangan model bisnis kanvas CV Kandura Keramik Bandung. Jurnal Aplikasi Manajemen 14(1): 88-97.

Rochman N, Sa'id EG, Daryanto A, Nuryantono N. 2011. Analysis of Indonesian agroindustry competitivness in nanotechnology development perspective using SWOT-AHP Method. International Journal of Business and Management 6(8): 235-244.

Roeshardianto P, Siregar H, Lukitawaty. 2015. Formulating risk mitigation strategies on the engineering, procurement and construction(EPC) project in mini hydro power plant development. Jurnal Aplikasi Manajemen 13(2): 175-185.

Saksono GA. 2013. Kanvas model bisnis PT. Fuel Technologies Group Indonesia [tesis]. Bogor: Institut Pertanian Bogor.

Simbar S. 2013. Optimalisasi strategi bisnis tower sharing. Jurnal Telekomunikasi dan Komputer 4(2): 99-118.

Umar H. 2010. Desain Penelitian Manajemen Strategik: Cara Mudah Meneliti Masalah-masalah Manajemen Strategik Untuk Skripsi, Thesis, dan Praktik Bisnis. Jakarta: Rajawali Pers. 